\title{
A representação do empoderamento feminino na
}

\section{teledramaturgia brasileira}

The Representation of Feminine Empowerment in the Brazilian Teledramaturgy

La representación del empoderamiento femenino en la teledramaturgia brasileña

Jéfferson Balbino ${ }^{1}$

'Universidad Estadual Paulista "Júlio de Mesquita Filho", Brasil.

Correo electrónico: jeffersonbalbino@bol.com.br

\section{Resumo}

Entre 1979 e 1980 foi ao ar, pela TV Globo, a série Malu Mulher, estrelada pela atriz Regina Duarte. Criada pelo diretor Daniel Filho, a série é um marco na história da teledramaturgia brasileira, haja vista que foi uma obra midiática que tinha como foco barrar o conservadorismo vigente em nossa sociedade trazendo para o centro de discussões o novo perfil da mulher brasileira: independente e dona de si própria. A série tinha a missão de debater temas sociais que viria, sobretudo, nas décadas seguintes, se tornar pauta na agenda feminista como, por exemplo, divórcio, aborto, métodos contraceptivos, maternidade, violência doméstica, homossexualidade feminina, menopausa, preconceito contra as mulheres desquitadas, infidelidade, primeira menstruação... Para este 


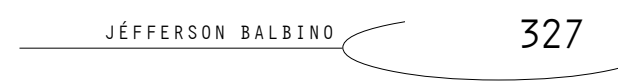

estudo faremos uso do box de DVD 's, que contém nove episódios, da série Malu Mulher, lançada pela Globo Marcas, em 2006. Objetivaremos, nesse texto, estudar como houve a representação da emancipação feminina através dessa série de televisão. Para tal intento, corroboremo-nos nas teorias de algumas historiadoras com importantes estudos feministas, dentre elas: Raquel de Barros Miguel e Carmen Rial (2012), Maria Zilda Matos e Andrea Borelli (2012) e Carla Bassanezi Pinksy (2014).

Palauras-chave: teledramaturgia, representação, emancipação feminina, sociedade

\section{Abstract}

Between 1979 and 1980 the series Malu Woman was aired on Globo TV, starring actress Regina Duarte. Created by director Daniel Filho, the series is a milestone in the history of brazilian teledramaturgy, given that it was a media work that had as its focus the barring of conservatism in our society bringing to the discussion center the new profile of brazilian women: independent and owner of herself. The series had the mission of discussing social issues that would come, especially, in the following decades, to become agenda in the feminist agenda as, for example, divorce, abortion, contraceptive methods, maternity, domestic violence, feminine homosexuality, menopause, prejudice against women unhappiness, infidelity, first menstruation... For this study we will use the DVD box, which contains nine episodes, from the series Malu Woman, launched by Globo Brands in 2006. In this chapter, we will study how there was representation of female emancipation through 


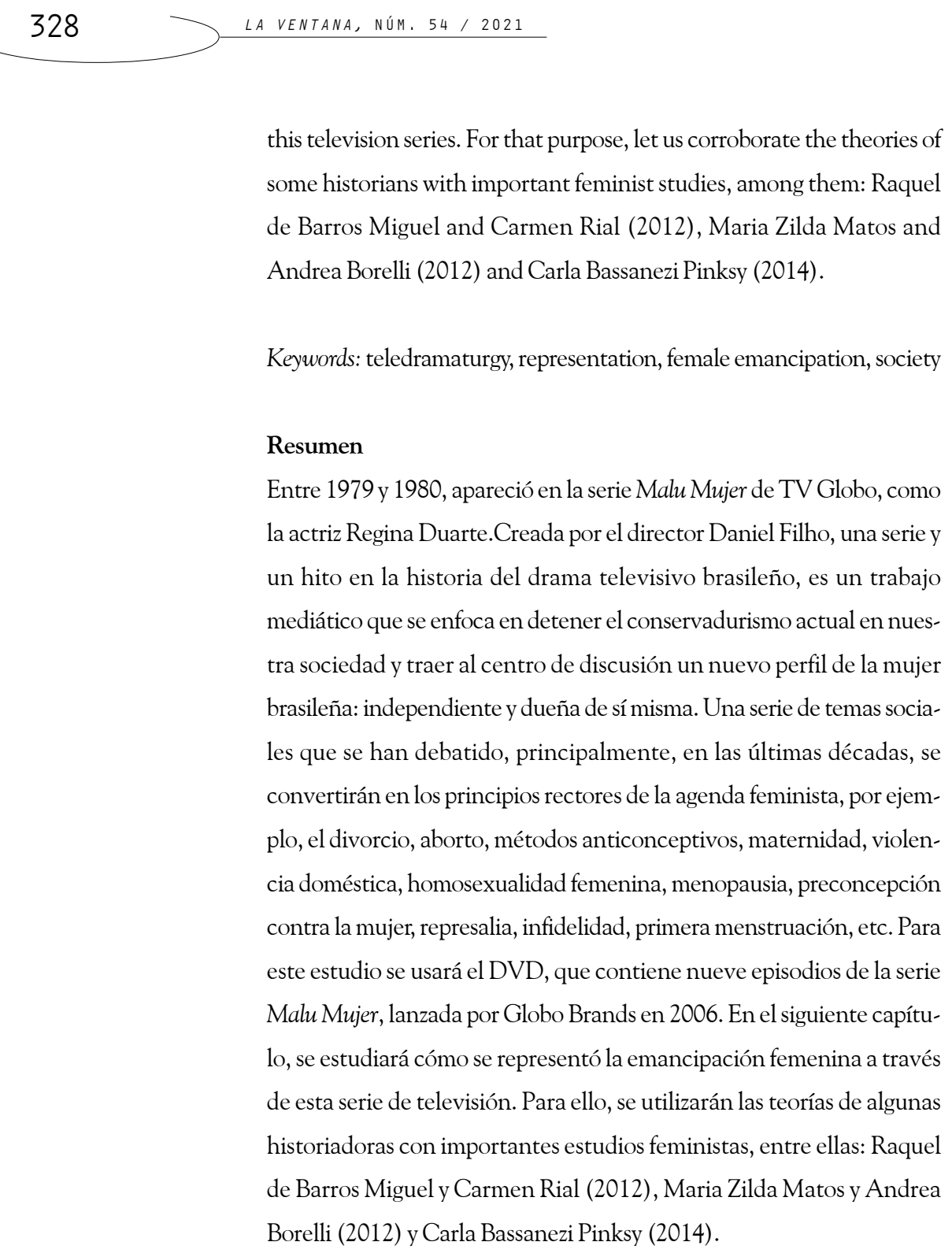


Palabras clave: representación, emancipación feminina, sociedad

RECEPCIÓN: 7 DE AGOSTO DE 2020/ACEPTACIÓN: 10 DE FEBRERO DE 2021

\section{Introdução}

A série brasileira Malu Mulher foi ao ar, pela TV Globo, entre 24 de maio de 1979 a 22 de dezembro de 1980, exibida em 76 episódios, às quintas-feiras (no primeiro ano de exibição) e às segundas-feiras (no segundo ano de exibição), às 22 horas. A série foi idealizada por Daniel Filho e escrita por Armando Costa, Lenita Plonczynski, Renata Palottini, Manoel Carlos e Euclides Marinho. E contou com a direção de Daniel Filho, Paulo Afonso Grisolli e Dennis Carvalho e produção de Maria Carmem Barbosa. Foi também inspirada no filme norte-americano Uma Mulher Descasada, de Paul Mazurkis. Malu Mulher tinha como objetivo "compor um retrato da condição da mulher brasileira, mostrando as dificuldades que ela enfrenta no cotidiano". (Dicionário da TV Globo, 2003, p. 386).

Malu Mulher narra as experiências vivenciadas pela jovem Maria Lúcia, Malu (Regina Duarte), uma socióloga que viria a ser uma mulher desquitada, com 32 anos, e com uma filha adolescente, Elisa (Narjara Turetta), de 12 anos. Cabe ressaltar que foi a própria atriz Regina Duarte que deu nome à sua personagem. (Memória Globo, 2008, p. 180). 
A narrativa se inicia com a protagonista Malu determinada a romper seu casamento com Pedro Henrique (Dênnis Carvalho). À margem de Malu surge, ao longo da série, outras mulheres que enfrentam diversos problemas sociais, inclusive, temas presentes na pauta feminista como, por exemplo, aborto, mulheres no mercado de trabalho, divórcio, a luta feminina pela independência, etc.

A composição da personagem central da série foi algo construído por várias mãos, uma vez que para chegar a Malu muitas ideias foram debatidas com a equipe da série (que era em sua maioria composta por mulheres). Não foi por mero acaso que Malu era socióloga por formação, afinal, para viver uma mulher transgressora que questionava a todo tempo a hierarquização machista que imperava (e ainda impera) em nossa sociedade, somente poderia ser uma mulher com ideais vanguardistas e ser socióloga era a profissão mais que ideal para ela seguir. A equipe da série chegou a esse consenso, em relação à profissão da personagem-título, após a socióloga e ex-primeira-dama Ruth Cardoso, muito amiga da atriz Regina Duarte, ter participado de uma reunião com a equipe da série. Outro fato que propagou a certeza da escolha da profissão de Malu se deu pelo fato de que a esposa do roteirista Euclydes Marinho, a Denise Bandeira, ser também socióloga. (Daniel Filho, 2001, p. 92).

Segundo o diretor Daniel Filho, o tom realista da série ocorreu a partir de uma "indicação de dona Ruth" para que os pesquisadores da equipe fossem até a UNICAMP (Universidade Estadual de Campinas), visto que "que na época era o máximo de vanguarda 
em sociologia". Sendo assim, a pesquisadora da TV Globo, Cristina Médicis esteve na universidade para entrar em contato com acadêmicas de sociologia e foi "de gravador em punho, pesquisando o que era ser uma socióloga e fotografando as casas delas" (Daniel Filho, 2001, pp. 92-93). Portanto, foi necessária a realização de uma profícua pesquisa para dar o tom de verossimilhança para a socióloga Malu. Inclusive, o cenário da casa de Malu foi inspirado nas casas das sociólogas entrevistadas nessa pesquisa, afinal em suas casas "sempre tinha uma decoração indígena, uma coisa meio de antropóloga" (Daniel Filho, 2001, p. 93).

Malu é apresentada para o público de duas maneiras: i) como uma mulher insegura, com incertezas e que lutava para conquistar um espaço no mercado de trabalho; ii) E, posteriormente, (no segundo ano da série) a personagem é a representação de uma mulher madura, com vida financeira estável e com um estado emocional equilibrado. A respeito disso, o Dicionário da TV Globo aponta que

A partir de 1980, a protagonista está mais amadurecida e consegue um trabalho fixo num instituto de pesquisa. Com isso, inicia-se uma nova fase em sua vida: a tranqüilidade proporcionada pela quitação do apartamento, a compra de um carro em bom estado e a contratação de uma empregada. Com essa estabilidade, Malu está preparada para pensar mais em si mesma e em seus problemas, pronta a recomeçar sua vida afetiva. (Dicionário da TV Globo, 2003, p. 386) 
Posto isto, observa-se que a guinada na vida da personagem principal acontece de maneira gradativa o que de certa forma 'instrui' a mulher que vivencia situação parecida a de Malu no início da separação: com filha menor de idade, desempregada e tendo que viver apenas com uma baixa pensão alimentícia.

No segundo ano da série, a personagem-título é representada como uma mulher ainda mais independente, realizada profissionalmente, com a filha bem instruída... E assim demonstra ao grande público que a mulher pode conquistar tudo o que ela quiser, mesmo não tendo um marido para se amparar.

Em consonância a isso, na obra Nova História das Mulheres no Brasil, às historiadoras Raquel de Barros Miguel e Carmen Rial, no capítulo Programa de Mulher, trazem um estudo sobre como a mulher conquistou, mesmo que aos poucos, o seu espaço de sociabilidade:

A mulher conquistou, aos poucos, o poder de escolher como passar seu tempo considerado livre. Ainda que as mulheres não estejam isentas de pré-julgamentos, hoje, praticamente todas as atividades de lazer lhes são possíveis. Mesmo diante de muitas permanências - calcadas, especialmente, nas ideias tradicionais do papel feminino -, mudanças são visíveis no campo do lazer das mulheres. (Miguel y Rial en Pinski, 2016, p. 166)

Essa teoria de Miguel e Rial pode, perfeitamente, ser aplicado à Malu, já que ela é a representação dessa mulher que foi, gradativamente, conquistando sua liberdade. E, é por mulheres como Malu -e outras 
vanguardistas que se destacavam nos anos 1960/1970-que atividades comuns em nossa contemporaneidade soa como algo corriqueiro, por exemplo, a "mulher viajar sozinha, ir à praia de biquíni, escolher o que ler ou ver no cinema (ou navegar na internet) sem restrições são, na verdade, frutos de conquistas lentas de mulheres de outras gerações” (Miguel y Rial en Pinsky, 2016, p. 165).

\section{Um breve painel da sociedade brasileira entre 1979 e 1980}

A transição das décadas de 1960 para 1970 marcou o início da grande revolução sexual que abriu as portas para a chamada 'liberdade de gênero'. Esse período pode ser, coincidentemente, marcado pelo ato de transgressão em "dar voz à luta contra a opressão social causada pelas categorias fixas de masculinidade e feminilidade, contra a imposição obrigatória da vinculação entre sexo e gênero". (Ribeiro, 2010, p. 36).

Em referência a mobilização que acomete em torno da pauta feminina nos anos 1970, a historiadora Claricia Otto, da Universidade Federal de Santa Catarina, em seu artigo O Feminino no Brasil: suas múltiplas faces, oriundo da Uma História do Feminismo no Brasil, de autoria da também historiadora Céli Regina Jardim Pinto (2003) esclarece que:

Entre os eventos que marcaram a entrada definitiva das mulheres e das questões por elas levantadas, na esfera pública, destaca-se ainda o Ano Internacional da Mulher, em 1975, 
decretado pela Organização das Nações Unidas (ONU). O feminismo no Brasil se fortalece com o evento organizado para comemorar o Ano Internacional, realizado no Rio de Janeiro sob o título "O papel e o comportamento da mulher na realidade brasileira", e com a criação do Centro de Desenvolvimento da Mulher Brasileira. [...]. O ano de 1975 foi também o da organização do Movimento Feminino pela Anistia, fundado por Terezinha Zerbini. As mulheres exiladas nos Estados Unidos e na Europa voltavam para o Brasil trazendo uma nova forma de pensar sua condição de mulher, em que somente os papéis de mãe, companheira e esposa (submissa e dócil) não mais serviam. (Otto, 2004, p. 239)

Partindo para o contexto político da época, sabe-se que no final dos anos 1970, o Brasil era comandado pelo general João Baptista de Oliveira Figueiredo que é considerado o "presidente da abertura política", na reta final da Ditadura Militar no Brasil.

Pode-se dizer que os anos 1980 começam ainda em 1977, pois foi o ano que surgiu a chamada dance music, inspirada no filme Saturday Night Fever (Os Embalos de Sábado à Noite). No Brasil, essa efervescência trouxe o glamour e o brilho das discotecas, o que fez os jovens brasileiros acolherem esse estilo em detrimento do hippie, a tendência anterior.

Nesse período, houve ainda um substancial aumento no número de academias de ginásticas no Brasil. As pessoas que frequentavam eram adeptas ao uso de collants e polainas para frequentarem as 
aulas de aeróbicas. O jeans, o gel nos cabelos e os tênis também conquistou a predileção dos jovens e até das pessoas mais velhas daquela época.

Em 1978, a Emenda Constitucional no․ 11 revogou o AI-5. E, em 1979, o general Figueiredo assinou o projeto de anistia que, nessa conjuntura, não era favorável aos terroristas, militares e funcionários com cargos cassados.

Ainda em 1979, houve a reforma partidária que colocou fim ao bipartidarismo no Brasil, algo que beneficiou a sociedade visto que propiciou o surgimento de uma abertura democrática basta ver que com isso foi possível a criação de novos partidos políticos como, por exemplo, PT (Partido dos Trabalhadores), PMDB (Partido do Movimento Democrático Brasileiro), PTB (Partido Trabalhista Brasileiro) e PSD (Partido Social Democrático). Portanto, nesse período houve -por parte do Congresso Nacional- a extinção da Arena e do MDB que eram as únicas esferas do bipartidarismo brasileiro.

Também, foi nesse período que houve a aprovação da lei de Anistia; as primeiras eleições diretas para governador; a transformação em Estado do território rondoniense; a aprovação do novo Estatuto dos Estrangeiros e a derrota, no Congresso Nacional, da emenda Dante de Oliveira que propunha eleições diretas para a presidência da República. (Escola Viva, 1998, p. 38).

Nessa conjuntura historiográfica há a inserção do feminismo, no Brasil, que acontece por influência dos pensamentos das escritoras Betty Friedan e Glória Steinem, nos anos 1960, e por Germaine 
Greer, nos anos 1970. Todavia, no Brasil o feminismo acontecia de maneira diferenciada do que ocorria em outras partes do mundo, tendo em conta que a ditadura militar regia o país. A despeito disso, Barreira (2003) argumenta que ao contrário do movimento feminista de outros países "que era influenciado por uma democracia que expunha de forma aberta a especificidade das lutas sociais das mulheres, no Brasil o paradoxo estava na dimensão da luta unitária contra a ditadura e a busca de um feminismo mais autônomo". (Barreira, 2003, pp. 136-137).

Em 1979, a música brasileira denuncia as arbitrariedades do sistema machista que reinava (e ainda reina), desde do surgimento da sociedade brasileira. A cantora Ângela Ro-Ro trazia, em seu disco de estreia, a questão da emancipação feminina na canção Agito e Uso, composta pela mesma. Nessa música, a cantora externaliza todo seu anseio de mulher por liberdade e por igualdade, demonstrando ser veementemente contra as práticas abusivas. A cantora trouxe nessa e em outras canções de seu disco de estreia temas polêmicos e que desafiava todos os padrões da época. Por toda essa altivez que Ângela Ro-Ro (homossexual assumida) não hesita em mandar "as regrinhas do bom comportamento para as cucuias".

Voltando para o exame da série, cabe ressaltar que Malu Mulher também, "reuniu números musicais e depoimentos de cantoras e compositoras brasileiras, tendo como foco principal a atuação feminina na Música Popular Brasileira" (Dicionário da TV Globo, 2003 , p. 387). Com uma trilha sonora composta por grandes nomes 
femininos da música brasileira como: Gal Costa, Maria Bethânia, Rita Lee, Elis Regina, Fafá de Belém, Marina, Simone, Zezé Motta, Joanna e Quarteto em Cy, a série não apenas projetou a obra das respectivas cantoras como demonstrou que o palco é também lugar de mulher.

Portanto, a cultura brasileira já pré-anunciava novos tempos da mulher em espaços de sociabilidade. E foi, justamente, nesse período de efervescência sociocultural que a TV Globo lançou a série Malu Mulher trazendo para a tela da televisão "várias das questões que eram discutidas nas centenas de grupos de mulheres que foram criados no país nessa época", ou seja, os temas da pauta do movimento feminista brasileiro (Corrêa, 2001, p. 16).

Nos anos 1980, as mulheres ingressam de maneira concreta no mercado de trabalho. E algumas delas almejando reivindicar cargos maiores como, por exemplo, os de chefia, passaram a adotar um visual mais próximo ao masculino, isto é, calças com cinturas altas e ombreiras nos blazers.

O crescimento da partição feminina no mercado de trabalho é uma das maiores transformações ocorridas na sociedade brasileira. A inserção das mulheres no mercado de trabalho ocorre, sobretudo, devido à necessidade econômica, motivada pela busca de uma complementação da renda familiar.

No Brasil, a década de 1980 é também marcada pelo fato de ser quando o feminismo enfrentou a redemocratização brasileira e quando começou a expandir na Academia o número de pesquisas sobre estudos feministas. Assim sendo, nesse período 
[...] duas questões tiveram de ser enfrentadas: a unidade do movimento ameaçada pela reforma partidária de 1979, que dividiu as oposições, e a relação do movimento feminista com os governos democráticos que viriam a se estabelecer, principalmente quando o Partido Democrático Brasileiro (PMDB) começou a ganhar as eleições estaduais. Surgiram grupos feministas temáticos, como também houve espaço para o surgimento e o feminismo acadêmico, ancorado no Departamento de Pesquisa da Fundação Carlos Chagas, em São Paulo, e em pesquisas de ciências humanas e educação realizadas nas grandes universidades do país, em algumas das quais surgiram Núcleos de Pesquisa em Estudos da Mulher. (Otto, 2004, pp. 239-240)

Graças ao empenho do movimento feminista que ao longo da década de 1980 começaram a aparecer às conquistas de tantas lutas como a implantação do Programa de Atenção Integral à Saúde da Mulher (PAISM), criado pelo Ministério da Saúde, programa este que "envolvia três temas: planejamento familiar, sexualidade e aborto" (Otto, 2004, p. 240).

No livro Nova História das Mulheres no Brasil, organizado por Carla Bassanezi Pinsky e Joana Maria Pedro, as historiadoras Maria Izilda Matos e Andrea Borreli relatam como transcorreu a interposição feminina no mercado de trabalho brasileiro:

No Brasil, a legislação que regulamenta o trabalho feminino foi implantada de forma assistemática, iniciando-se nos finais 


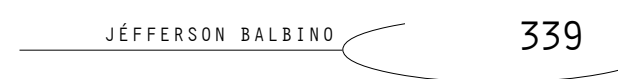

da década de 1910, pelo estado de São Paulo. Nos anos 1930, cresceu a interferência federal na órbita da regulamentação do trabalho e, no que se refere às mulheres, culminou no item "Da proteção ao trabalho da mulher" da CLT (1943). Por meio dele, ficou estabelecida a equiparação salarial entre homens e mulheres. Além disso, coibiu-se a participação de mulheres em tarefas inadequadas a sua capacidade física e/ou que colocassem em risco a saúde feminina. Com exceção dos empregos em telefonia, radiotelefonia, enfermagem, casas de espetáculos e diversão, hotéis e bares, o trabalho noturno também foi vetado às mulheres. Regulamentou-se ainda a licença-maternidade e a exigência de creches em empresas com mais de 30 trabalhadoras. Entretanto, apesar dessas medidas, discriminações, ilegalidades e abusos continuaram a persistir por décadas. (Matos y Borelli en Pinsky, 2016, pp. 141-142)

Não obstante, as historiadoras alegam que:

[...] as mulheres só adquiriram o direito de trabalhar sem a autorização do marido em 1943 e apenas com o Estatuto da Mulher Casada (1962) é que se retirou do Código Civil o direito do marido de impedir sua esposa de trabalhar fora do domicílio. A partir da década de 1960, novas leis foram criadas no sentido de coibir as diferenças por motivos de sexo com relação a salários, critérios de admissão, exercício das 
funções e promoção na carreira. A licença-maternidade foi ampliada para 120 dias, sem prejuízo do salário, e deu garantias de estabilidade à gestante (1988), sendo os benefícios estendidos também às mães adotivas (2002). (Matos y Borelli en Pinsky, 2016, p. 142)

Matos \& Borelli ainda afirmam que o Estado sempre interferiu com ambiguidade no trabalho feminino visto que ora reforçava "a importância da maternidade e os cuidados femininos do lar", ora facilitava a incorporação feminina ao mercado de trabalho, justamente, por necessitar dessa mão de obra feminina.

Sobre isso as historiadoras ponderam que:

A partir da década de 1960, a empregabilidade feminina cresceria de forma sistemática tornando-se constante, intensa e diversificada. Vários elementos contribuíram para tanto. A redução do poder de compra e o arrocho salarial colocaram em xeque a sobrevivência e capacidade de consumo das famílias, levando mulheres de setores populares ao mercado de trabalho. Mudanças comportamentais (trazidas pelos movimentos feministas e de contracultura) alimentaram novas expectativas femininas, despertando o desejo de autonomia financeira e de realização profissional nas mulheres das camadas médias. (Matos y Borelli en Pinsky, 2016, pp. 142-143). 
Ainda, nos anos 1980, algumas mulheres brasileiras passaram a incorporar em seu visual um estilo mais extravagante como, por exemplo, o uso de minissaia com legging, bermudas mais curtas e macacões, sendo essas roupas - em sua maioria - em cores excêntricas. Houve, também, nesse período o uso de maquiagens muito mais fortes como o uso de batons vermelhos.

\section{Ensinamentos através da ficção}

A série Malu Mulher contribuiu para fortalecer a emancipação feminina, pois tratou - mesmo que de modo sutil e/ou incipiente de temas inerentes à pauta feminista, algo que contribuiu na luta do movimento feminista.

Antes de adentrarmos na análise dos episódios da série, cabe alguns esclarecimentos em relação a metodologia utilizada para tal análise. Para esse estudo utilizamos os nove episódios que compõem o box de DVD’s, lançado pela Globo Marcas, em 2006. Como é a premissa desse segmento audiovisual, geralmente, são selecionados para integrar esses compêndios os episódios de maior sucesso e repercussão junto à crítica e ao público.

Cada episódio foi assistido por duas vezes, sendo a primeira delas uma visão despretensiosa (de um mero telespectador) e a segunda uma visão mais atenta (de pesquisador), isto é, observando as intencionalidades por trás dos diálogos, dos gestos, das roupas das personagens, da caracterização, da trilha sonora e também dos cenários. Os dados extraídos a partir dessa visualização eram ano- 
tados para depois serem confrontados com as fontes e assim amplamente analisados.

A seguir, veremos o modo como foi abordado determinados temas e em que medida se deu sua contribuição para o avanço (ou debate) das pautas feministas na sociedade brasileira.

No episódio de estreia, intitulado Acabou-se o que era doce, de autoria do roteirista Euclydes Marinho, exibido originalmente em 24/05/1979, o público conhece o estágio crítico -que culminaria em separação- do casal Malu e Pedro Henrique.

Pedro Henrique representa o protótipo do marido infiel e que não faz questão de dar a devida atenção para sua esposa e filha. Entretanto, Malu é uma esposa que exige o que lhe é de direito: um marido fiel e atencioso com a família. Como não consegue por vias naturais trazer o marido para assumir o papel que lhe cabe, Malu -com sua personalidade questionadora e contestadora- não aceita continuar vivenciando com naturalidade aquela situação de desgaste conjugal. Contudo, seu marido se recusa a discutir a relação, pois "casamento é assim mesmo" -como ele afirma-, e pede que a mulher procure uma psicóloga e psicanalista para sanar todas suas indagações conjugais. É quando Pedro e Malu se exaltam durante a discussão e Malu acaba sendo agredida pelo marido.

Na época de exibição da série não existia a Lei Maria

${ }^{2}$ Lein. 11.340/2006. Surgiu com o intuito de amparar e proteger as mulheres brasileiras agredidas por seus cônjuges. da Penha e as leis brasileiras existentes, diferentemente de hoje, não condenavam como crime agressão verbal e física contra as mulheres. 


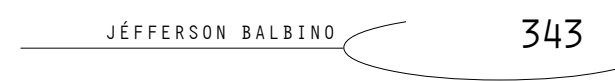

Os diálogos proferidos por Malu, nesse primeiro episódio, são vanguardistas para o período em que foi exibido:

- "Você nem pensa em encostar a mão em mim de novo. Te boto na cadeia!";

- "Mata, mata de uma vez" [grita Malu ao levar uma bofetada no rosto];

- "Mulher não pode ser fragilzinha, tem que ser agressiva de vez em quando, saber se defender";

- "A caderneta de poupança tem sido brilhante, mas... já como marido...";

- "Acabou tudo, quero que você vai embora".

Nesses diálogos proferidos na briga de Malu e Pedro Henrique fica evidente os atributos da causa feminista. Além do que soa como se Malu estivesse ensinando outras mulheres (no caso, as telespectadoras) a se defenderem numa situação parecida.

No episódio Ainda não é a hora, de autoria de Euclydes Marinho, exibido originalmente em 14/06/1979, a série trouxe como problemática as questões inerentes ao aborto, a necessidade de sua legalização e o perigo que acomete a saúde das mulheres nas clinicas clandestinas. Jô (Lucélia Santos), filha do porteiro do prédio que Malu mora, descobre que está grávida do namorado Jorginho (Fábio Jr.), como ainda estão na adolescência, estudando e sem emprego ela acredita ser melhor interromper a gravidez, uma vez que crê não possuir condições financeiras e até mesmo psicológicas para ser mãe naquele momento. 
Malu leva Jô para uma consulta com seu ginecologista, o Dr. Pompeu (Fábio Sabag). No entanto, Pompeu se recusa a fazer o aborto voluntário de Jô, visto que é proibido por lei. Sendo assim, Jô pede ajuda de Malu para levá-la numa clínica médica clandestina que faz, de maneira ilegal, abortos. Ocorre que após o procedimento, Jô apresenta uma hemorragia e necessita com urgência de cuidados médicos num hospital. E, é quando se desenvolve um dos mais promissores diálogos feministas da série que, inclusive, evidencia a mídia como construidora e normatizadora de discursos de gênero. Malu, em conversa com o médico que é contrário ao fato da mulher decidir abortar uma gravidez, chama atenção da sociedade para esse problema tão sério que é a criminalização do aborto, maiormente, movido por preceitos e dogmas religiosos. Vejamos:

MALU - Mas o que é que se pode fazer, enquanto não for legalizado? As infelizes das mulheres estão nas mãos deles [dos médicos clandestinos] mesmo. Todo mundo condena, diz que é crime, diz que é pecado, mas na hora todo mundo fecha os olhos porque um dia pode precisar. Isso chama-se hipocrisia. [...]. Se é necessário, se é uma coisa inevitável, porque não legalizar? Por que não tornar menos sórdido, mais civilizado?

Nesse episódio, em questão, Malu, demonstra ser uma mulher feminista, afinal, apoiou a decisão individual de Jô em interromper sua gravidez. 


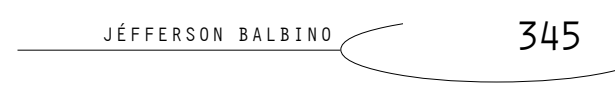

Malu, também repudia a hipocrisia da sociedade criminalizar o aborto. Entretanto, seus diálogos ao longo do episódio procuram promover uma disseminação de informações precisas em relação ao uso dos métodos contraceptivos disponíveis, ou seja, através de seu discurso Malu 'ensina' como a mulher pode se prevenir para evitar uma gravidez indesejada.

A respeito do controle de natalidade, Matos y Borelli destaca que:

A divulgação de novas possibilidades no controle da natalidade, como a difusão do consumo da pílula contraceptiva, possibilitou às mulheres escolher o número de filhos, diminuir e/ou postergar a maternidade, influenciando a entrada e permanência feminina no mercado de trabalho. Contribuiu ainda para incrementar a capacidade de investir nas carreiras profissionais. (Matos y Borelli en Pinsky, 2016, p. 143)

No episódio Com unhas e dentes, escrito por Manoel Carlos, exibido originalmente em 30/08/1979, a personagem Malu traz dados estatísticos a respeito do crescente número de desquites nas capitais brasileiras. Embora esteja comentando essas informações para sua filha pré-adolescente, Elisa, ela está na verdade compartilhando esses dados (que são verídicos) com diversas mulheres que estão acompanhando a série. Inclusive, aquelas mulheres com baixo letramento que sequer tinham consciência do alarmante crescimento de desquites pelo país. 
Não obstante, no referido episódio, Malu ajuda uma prima, que mora no interior de Minas Gerais, e que se casa virgem aos 31 anos, a lidar com a angústia da virgindade e a iminência da primeira relação sexual que irá ter com seu marido.

Com referência a virgindade feminina a historiadora Carla Bassanezi Pinski (2014), faz a seguinte menção explicativa:

Mesmo com todas as mudanças sociais ocorridas na primeira metade do século XX, a regra que obriga as moças a conservarem a virgindade até o casamento permanece com toda força. São raros os homens que admitem se casar com uma mulher 'deflorada por outro'. A anulação do casamento devido à constatação de que a noiva não é virgem está prevista pelo Código Civil, e o Código Penal, por sua vez, reserva punições para o "induzimento a erro essencial" (engano quanto à virgindade da noiva) e o "crime de sedução". (Pinski, 2014, pp. 123-124)

Nesse episódio, Malu reconhece "ter vergonha de não ter conseguido ser feliz com um mesmo homem a vida inteira”. É também abordado o preconceito contra as mulheres desquitas, uma vez que o pai de Malu pede que ela não revele para a família, do interior de Minas Gerais, que está desquitada de Pedro Henrique, pois "nunca houve na família uma mulher desquitada”.

Em A amiga, escrito por Euclydes Marinho, exibido originalmente em 11/10/1979, Malu está separada há 9 meses de Pedro Henrique e 
muito carente se apaixona por seu chefe, Paulo (Ney Latorraca), entretanto, se assusta com esse novo sentimento que não é recíproco.

$\mathrm{O}$ ponto crucial do referido episódio acontece quando Malu descobre que o dono da empresa que trabalha demitiu sua colega de trabalho, Maria (Ângela Leal), pelo fato da mesma se recusar a ir para a cama com ele. Quando Malu toma ciência do ocorrido não titubeia e declara apoio inconteste a Maria e juntas redigem uma carta à imprensa denunciando o assédio moral/sexual do empresário.

Esse episódio discute algo que está em voga, atualmente, na sociedade brasileira: a questão do assédio, sobretudo, no ambiente profissional. Além disso, a série aborda nesse episódio a questão da homossexualidade feminina, quando numa determinada cena, Malu e Maria após beberem muito vinho (a ponto de se embriagarem) começam a falar de suas frustrantes experiências com seus ex-maridos. E de repente Malu adormece e Maria a leva ao quarto. $\mathrm{Na}$ seguinte cena, Malu aparece apenas de calcinha e sutiã lendo um bilhete que Maria havia lhe deixado ao lado de sua cama - fazendo uma alusão aos recados que alguns homens deixam para as mulheres após uma noite de amor, ou seja, o autor deixou subentendido que pôde ter ocorrido uma noite de amor entre Malu e Maria.

Um fato que desperta atenção nesse episódio ocorre em função da inexistência da palavra "homossexual" em seu roteiro. Em nenhum momento, nenhuma das personagens diz a palavra homossexual e/ ou homossexualidade, embora se trate do assunto, talvez, para dri- 
blar a Censura Federal a palavra homossexual foi substituída por "diferente" e "pervertida".

Na época, em declaração a Veja, o roteirista -que escreveu esse episódio- Euclydes Marinho afirmou que conforme as orientações de seu texto, era evidente que Malu e Maria tinham transado. Ele ainda destacou que esse episódio sofreu modificações pela Censura Federal devido seu teor.

O segundo disco do box da série Malu Mulher começa com o episódio Duas vezes mulher, escrito por Manoel Carlos, exibido originalmente em 21/04/1980, que aborda os temas: menopausa -através de Dona Elza (Sônia Guedes), a mãe de Malu- e primeira menstruação -através de Elisa (Narjara Turetta) - filha da protagonista.

Atentamos para esse dialogo sincero e repleto de cumplicidade entre Malu e Elza:

MALU - Por que essa crise agora? Fala comigo mamãe [desabafa Malu]. Eu sou tua filha, eu já fui casada, eu tenho uma filha que daqui a pouco tá moça, também. Que foi? Que foi que aconteceu?

ELZA - Seu pai, não é?! Não sei se eu tô ficando velha. [pausa] Também, eu tenho fugido dele. Não sei, não tenho vontade. Eu não sei se é uma coisa pra sempre. Ah, eu tenho até medo de pensar nessas coisas.

MALU - Claro que é uma fase... Eu sei, eu também tive uma fase assim com o Pedro Henrique, fugia dele na cama e era 


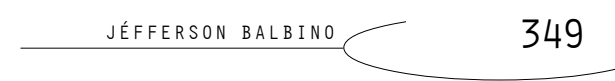

uma fase, eu nem era casada há tanto tempo com ele como você e o papai. E aí... sei lá... Acho que acontece com todo mundo, é tão comum.

ELZA (com repulso) - Eu sinto assim... um nojo filha.

MALU - Ah... mamãe.

ELZA - Depois tem feito um calor. E suor... Cheiro de cerveja. [...]. Eu não quero não, eu não quero mesmo! Faz mais de um mês que eu tô fugindo dele. Assim... no começo eu falei que tava com dor de cabeça, depois que eu tava com cólica e... depois eu não falei mais nada não. Só fiquei fugindo. Até que sexta-feira ele tentou mesmo, sabe? A força... Ele queria me violentar, meu Deus! [aflita]. Eu falei pra ele que eu iria gritar se ele tentasse, que eu ia fugir mesmo. Aí ele falou que ia pra rua procurar uma outra, meu Deus, nunca me senti tão humilhada. Eu queria morrer. [...].

MALU - Que grosseria, que coisa mais... Que falta de delicadeza com você numa hora que você tá precisando tanto dele. Eu não sei o que te dizer, mamãe. Eu não sei... Me parece que a tua sexualidade tá bastante condicionada a ideia da procriação. E que você, agora, não tem mais esse pretexto que te permitia ter algum prazer com relação... Agora você fica sem saber viver o prazer, pelo prazer. Só mesmo. E você fica com dificuldade de assumir isso: o prazer. E isso deve tá fundindo sua cabecinha, não?

ELZA - Cabecinha o que filha. Isso é físico mesmo... 
Ainda no referido episódio, há uma passagem em que Elza -devido sua crise com a chegada da menopausa-, afirma a Malu que não quer mais ter uma vida sexual ativa com o marido, pois vê sua sexualidade como uma obrigação e não como a consumação do amor e do prazer entre o casal. É louvável a abordagem trazida nesse episódio, pois tratou da falta de libido como algo biológico e não como religioso - algo muito frequente em tais tipos de representações.

O episódio Antes dos 40, depois dos 30, escrito por Manoel Carlos, exibido originalmente em 19/05/1980, mostra que Malu não é uma "supermulher", pelo contrário, afinal, também, sofre. E é, justamente, num momento de vulnerabilidade, desencadeado pelo aniversário e a famosa 'crise dos 30' que Malu -desquitada há alguns meses- se vê numa 'recaída' pelo ex-marido, Pedro Henrique. Tal constatação fica evidente no momento que a personagem diz pra si própria: "Você tá precisando de um marido, Malu. Mas antes dos 40. Depois fica difícil". Aqui, a série problematiza o senso comum (ainda existente!) que a mulher quando chega a maturidade não consegue mais se casar.

Em Filhos, melhor não tê-los, de autoria de Walther Negrão e Marta Góes, exibido originalmente em 25/08/1980, a série põe em foco a questão das mães que criam sozinhas seus filhos e, também, critica a burocracia do processo de adoção de crianças e, também, a dificuldade que essas mães enfrentam para se manter ou retornar ao mercado de trabalho. 


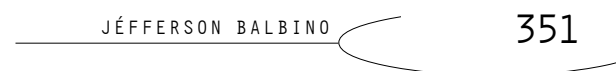

Esse episódio evidencia a ideia que a série almeja passar a despeito da valorização do trabalho feminino como algo que acarreta uma realização pessoal na mulher. Quando Eunice (Cidinha Milan), empregada doméstica, é demitida do apartamento vizinho ao de Malu por ter tido um filho, a série mostra a dura realidade das mulheres de classe baixa que veem no trabalho fora de casa não uma alternativa, mas, sim, uma possibilidade de complementação da renda familiar.

Outro ponto crucial narrado nesse episódio ocorre quando Eunice é confundida como prostituta pela polícia, inclusive, sofre violência sexual por tal constatação equivocada. Walther Negrão se inspirou no caso real "operação limpeza", criado pelo delegado Richetti, em 1980, que pretendia "limpar" a prostituição do centro histórico do Rio de Janeiro.

É perceptível, também, o questionamento de Malu -mesmo que de maneira indireta- ao regime militar. A personagem clamava pela chegada da abertura política, justamente, para ver a ampliação dos direitos da mulher.

No episódio Infidelidade, escrito por Armando Costa, exibido originalmente em 09/06/1980, o público se depara com uma Malu muito à frente do tempo das outras mulheres dessa época, pois o episódio como seu próprio título sugere, aborda questões circunscritas no campo da infidelidade e, é quando Malu -pela primeira vez em sua vida- se permite em sair com um homem casado. No entanto, cabe frisar que o casamento em questão estava em declínio à beira de uma separação. 
Nesse episódio chega a ser crível a vertente feminista da heroína da narrativa, uma vez que ela põe em discussão as desigualdades que recaem sobre as mulheres que se permitem a viver uma aventura amorosa e/ou sexual fora do que é tido como "normal" pela sociedade.

O episódio, ainda, discute acerca do casamento tradicional imbuído na ideia de instituição indissolúvel e com isso permite a propagação de uma reflexão no que tange a ideia de independência e, conseguintemente, autonomia da mulher.

No derradeiro episódio, do box de DVDs, intitulado Legítima defesa da honra e outras loucuras, de autoria de Armando Costa, exibido originalmente em 22/09/1980, é abordado a violência e agressão física contra a mulher. $\mathrm{O}$ referido episódio foi exibido originalmente na época de repercussão da morte de Ângela Diniz, assassinada brutalmente por Doca Street. Vale ressaltar que a expressão "defesa da honra" foi insanamente utilizada como argumento no momento de inocentar ou atenuar a pena dos agressores e homicidas.

A série Malu Mulher foi pioneira ao propor em horário nobre da televisão brasileira assuntos que são de interesses da sociedade, mas que muitas vezes são deixados de lado seja por pudor, preconceito ou por desconhecimento. Nesse sentido, a série idealizada por Daniel Filho traz uma imensurável contribuição social haja vista que possibilita um diálogo esclarecedor com o público acerca de assuntos relacionados ao direito da mulher.

Portanto, há uma grande necessidade de as emissoras de televisão produzir programas -seja eles de entretenimento ou não- que abor- 
de temas sociais como, nesse caso em específico, os direitos das mulheres, pois assim propiciará utilidade pública através do entretenimento. E, conseguintemente, com isso irá trazer informação para a sociedade e estimular a problematização e o debate de temas relevantes. Além de contribuir para a ampliação dos direitos das mulheres como também -a sua maneira- minimizar atos de violência e preconceito contra as mulheres. Ou seja, é uma maneira de instruir a mulher a não se inferiorar diante da figura masculina. Com isso conscientizará a mulher a respeito da importância de denunciar maridos e namorados que sejam agressores.

\section{Afronta aopoliticamente correto}

Uma das maiores constatações de que a série Malu Mulher esteve à frente de seu tempo se dá, também, pelo fato das personagens Malu e Pedro Henrique aparecerem em cena fumando na frente da filha Elisa. E isso ocorria numa época em que a Censura Federal, da Ditadura Militar, ainda estava em pleno vigor. Entretanto, devido ao início do processo de abertura política havia uma espécie de relaxamento nos órgãos que compunham a Censura aos programas televisivos. Sendo, por isso, que tais cenas eram escritas, gravadas e liberadas pelo órgão para serem exibidas na TV.

Mesmo com a Cesura Federal que se fazia presente nos governos da Ditadura Militar a equipe da série consegue a façanha de mostrar -num dos episódios que não estão reunidos no box lançado pela Globo Marcas- uma cena da protagonista Malu tendo um or- 
gasmo feminino na qual era mostrada apenas as mãos da heroína se abrindo num espasmo durante sua relação sexual com um novo namorado.

Como a protagonista da série Malu Mulher era uma mulher desquitada, cabe uma explanação melhor sobre o desquite. A lei do desquite (judicial e amigável) foi inserida no Código Civil Brasileiro, em 1916. Todavia, a lei não era abrangente, dado que limitava a liberdade dos desquitados e que ocasionava apenas os direitos dos cônjuges à bens materiais tornando excludente o desvinculo matrimonial. Na obra Mulheres dos Anos Dourados, Carla Pinsky tece a seguinte menção explicativa sobre o desquite no Brasil:

Até 1977, portanto, o casamento civil no Brasil é monogâmico e indissolúvel. O desquite, a forma legal de separação dos casais, não dissolve os laços conjugais, mesmo com a separação não pode haver um casamento posterior. O matrimônio só é dissolvido se for anulado ou se algum dos cônjuges vier a falecer. A sociedade conjugal e a obrigação da vida conjunta terminam com o desquite, mas o vínculo matrimonial continua existindo entre o casal. Com a separação da sociedade conjugal, cada membro torna-se independente do outro, mas há deveres que não se extinguem como: o da fidelidade, o da pensão alimentícia e o da guarda e criação dos filhos menores. $\mathrm{O}$ desquite pode ocorrer por mútuo consentimento (depois de dois anos de casados) ou por justa causa (se um dos cônjuges for considera- 
do culpado de algum dos seguintes motivos: adultério, com penas previstas no Código Penal; tentativa de morte; abandono voluntário do lar durante dois anos seguidos; sevicia ou injúria grave). (Pinski, 2014, pp. 247-348)

Sendo assim, a mulher uma vez desquitada levava consigo uma espécie de marca que lhe acompanharia para toda vida e que, muitas vezes, seria um grande empecilho para reconstruir sua vida amorosa com outro homem. Afinal, ela já era 'deflorada', além de que não poderia se casar novamente. Portanto, nessa conjuntura, mulheres desquitadas como Malu tinham que ter muita coragem para viver numa sociedade preconceituosa.

\section{Malu: o exemplo de mulher}

A personagem central da série, Malu, é repleta de nuances, uma vez que é calcada na verossimilitude, pois embora seja transgressora, Malu é, também, ingênua, ou seja, é "gente como a gente" - passível de ingenuidade. Outra característica forte dessa personagem é que a mesma possui ideais esquerdistas, socialistas, afinal, Malu sempre estava a favor dos direitos negados a minoria. Ela representava o arquétipo da mulher moderna aquela ideal para viver no século XXI, pois tinha um discurso embasado na luta e na independência feminina, além do respeito pelo corpo feminino.

A personagem central da narrativa tinha ainda um discurso atípico da maioria das mulheres das décadas de 1970 e 1980, pois a 
mesma destaca que a fidelidade não deve ser encarada como uma lei obrigatória como afirma ao longo do episódio Solidão: feminino, plural, de autoria de Manoel Carlos (e que também não está incluso dentre os episódios selecionados para compor o box de DVDs lançado pela Globo Marcas).

Malu é aquela mulher fiel aos seus sentimentos. E muito destemida, pois enfrenta os preconceitos por ser uma mulher desquitada, enfrenta o machismo, é plenamente a favor da legalização do aborto e da criminalização da violência contra as mulheres.

O modelo de feminilidade apresentado na personagem Malu é de uma mulher que trabalha fora do lar, que é independente e, acima de tudo, sincera, afinal diz -sem medo- o que pensa na cara de homens violentos.

Malu é, ainda, uma mulher que se sente realizada através da maternidade e que ensina a filha, Elisa, a ter autonomia por sua vida, pois "é importante ter um salário e uma profissão". Entretanto, também, passa para Elisa os ensinamentos que sua mãe lhe passou: cuidar da casa, saber cozinhar, lavar roupas e louça, ou seja, ensina a filha a ter autonomia em seu espaço doméstico. Porém, o que é mais louvável em Malu é, justamente, essa busca incessante que ela tem pela devida ampliação dos direitos das mulheres.

A personagem é uma mulher que luta incansavelmente para que haja uma igualdade de gênero e assim ser respeitada da mesma forma que um homem é respeitado numa sociedade patriarcal. 


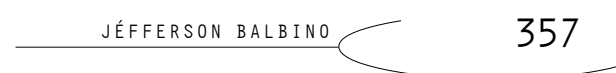

\section{Considerações finais}

A escolha da série brasileira Malu Mulher como objeto para essa pesquisa se deu por se tratar de uma série teleficcionada que tinha como foco as problemáticas concernentes ao universo da mulher mostrando as transgressões que as mesmas tiveram no final da década de 1970 e início da década de 1980.

Outro motivo que despertou a curiosidade em estudar esse seriado brasileiro transcorreu pelo fato de ter sido um produto audiovisual inovador e, conseguintemente, ousado que, a meu ver, conseguiu captar muito bem os anseios democráticos daquele contexto. Aliás, é por esses e outros fatores que a série Malu Mulher é considerada pelo público e pela crítica especializada como um retumbante sucesso da televisão brasileira, tendo sido exportada para diversos países como ainda sendo uma das obras da televisão brasileira mais premiada tanto no Brasil quanto no exterior.

E, por último, por se tratar de uma obra audiovisual que trouxe temas que necessitam estar de maneira constante na pauta da sociedade brasileira para gerar reflexões nos telespectadores que assistem. E a série Malu Mulher conseguiu -e com êxito- falar de temas que podem ser vistos como privados ou então de esfera familiar. Entretanto, a série conseguiu abordar (e por que não publicizar?) tais conteúdos de maneira altruísta e sem tratar como dramas pessoais, como vemos em outras obras audiovisuais como, por exemplo, nas telenovelas. 
A partir desse estudo foi possível perceber que a personagem da atriz Regina Duarte é uma mulher obstinada, que não se curva diante dos homens, nem mesmo daqueles machões que usam sua força física para minimizar -inutilmente- a figura da mulher. Malu é, ainda, a representação de uma mulher sagaz, capaz de dizer aquilo que esta "entalado" na garganta da maioria das mulheres. Contudo, Malu não é uma "mulher maravilha", afinal é passível de erro como todo e qualquer ser humano sendo também chorona, sonhadora, romântica, que se engana, que sente medo e que tem momentos de fraqueza, ou seja, é detentora dos mesmos conflitos e contradições humanas dos/das telespectadoras.

Outra constatação preponderante através da série brasileira Malu Mulher é que não é o homem -ou todo arquetípico masculino e proveniente do machismo de alguns personagens masculinos- que são os grandes vilões representados na narrativa, mas, sim as atitudes comportamentais que parte dos homens prefere adotar deixando se possuir pelo machismo, preconceitos, hipocrisia, opressão e violência, como se tais atitudes fossem necessárias para legitimar sua respectiva masculinidade e assim forjar uma submissão feminina.

A série Malu Mulher foi eficaz na popularização de temas feministas que não conseguiam amplos espaços para serem debatidos pela sociedade e por ser uma obra veiculada num meio de comunicação democrático, como é o caso da televisão, a mensagem passada através da personagem, Malu, chegou à diversas mulheres brasileiras -da mulher não alfabetizada até a mulher mais culta-e, 
também, para o público masculino perpassando junto aos homens que cometem agressões, violência e desrespeito com suas mulheres.

Sendo assim, creio que a série brasileira Malu Mulher, trouxe contribuição muito para a sociedade brasileira, pois trouxe uma representação da mulher moderna que se desprendia da submissão que lhe fora imposta até então. E também por instruir a mulher a desprender do medo e da passividade em relação ao seu comportamento diante da figura masculina.

A série Malu Mulher foi responsável por tocar 'o dedo na ferida' em pleno horário nobre da TV brasileira trazendo toda a polemicidade que os importantes temas presentes na pauta feminista que, inclusive, ainda são temas concordantes da esquerdapolítica brasileira.

Malu mostrou a todas e a todos que a mulher não é um ser frágil como muitos machistas deduzem, muito pelo contrário, as mulheres vêm provando ao longo do tempo (e da história) que são muito mais fortes do que se imagina.

Através do seriado em questão podemos vislumbrar o redesenhamento que a feminilidade vem traçando desde as primeiras décadas do século passado quando o feminismo esteve intrinsecamente relacionado ao esforço pessoal de mulheres renomadas que desbravaram seus próprios pudores para romper com dogmas e conceitos estabelecidos.

Graças as lideranças femininas -sendo muitas delas mulheres que ainda estão submersas ao anonimato- que as mulheres de hoje, dessas primeiras décadas do século XXI, podem usufruir e "respirar" 
ares de liberdade ainda que seja uma liberdade camuflada, limitada, repudiada e sexista. Todavia, ao olharmos de maneira reminiscente constatamos que muito já foi feito, em contrapartida, ao olharmos de maneira visionária concluímos que ainda há muito a ser feito em prol do empoderamento, da emancipação feminina, da liberdade e igualdade de gêneros.

E, sendo assim, fica evidente a importância que existe na representação feminina libertadora, seja ela na televisão, na publicidade, no cinema, na literatura, na música ou em que âmbito seja. Afinal, lugar de mulher é onde ela quiser estar e não onde o homem deseja que ela esteja.

\section{Bibliografia:}

Barreira, F. (2003). Uma História do Feminismo no Brasil. Revista de Ciências Sociais. 34(1), 135-138. www.repositorio.ufc.br/bitstream/ riufc/9815/1/2003_art_iafbarreira.pdf.

CorrêA, S. (2001). Do feminismo aos estudos de gênero no Brasil: um exemplo pessoal. Cadernos Pagu. (16), 13-30.

Dicionário Da Tv Globo. (2003). Programas de dramaturgia e entretenimento. Rio de Janeiro: Zahar.

Escola Viva. (1998). O tesouro do estudante. São Paulo: Meca.

FILHo, D. (2001). O Circo Eletrônico: fazendo TV no Brasil. Rio de Janeiro: Jorge Zahar Editor. http://www.scielo.br/ scielo.php?script $=$ sci_arttext\&pid=S0104-026X2004000200015. 


\section{jéfferson balbino}

Memória Globo. (2008). Almanaque da TV Globo. Rio de Janeiro: Editora

Globo.

Oтто. C. (2004). O Feminismo no Brasil: suas múltiplas faces. Estudos Feministas. 12 (2), 237-253.

Pinsky, B. (2014). Mulheres dos Anos Dourados. Revista Feminismos. 4(3), $181-185$.

Pinsky, B. y Pedro. J. (2016). Nova História das Mulheres no Brasil. São Paulo: Editora Contexto.

PInTo, J. (2003). Uma História do Feminismo no Brasil. São Paulo: Fundação Perseu Abramo.

Ribeiro. R. (2010). A TV no Armário: a identidade gay nos programas e telejornais brasileiros. São Paulo: Edições GLS. 